\title{
Self-Defense and Political Justification
}

\author{
Christopher Kutz $\dagger$
}

I am doubly honored to give these comments today, for they allow me to express my respect and gratitude for not one but two teachers and intellectual models, Sandy Kadish and Jeremy Waldron. In keeping with a major theme in Professor Waldron's work, the importance of disagreement, I shall try to express my regard by being as disagreeable as possible. This is not easy: I have little to add or subtract from his exegesis of Hobbes and Locke- there are others here who can play that role in discussion. Furthermore, I suspect he might agree with inany of the points I will go on to make. But here goes. I take up two ideas in this Response. First is the difficulty in bridging the gap between claims about what it is reasonable to expect an agent to do and what it is legitimate for the state to prohibit. Attention to this gap, I will suggest, reveals the limitations of purely agent-relative or agent-neutral justifications for self-defense, and indeed calls into question the extent to which they provide justifications at all. Second, I take up the relation between our obligations and what lies within our power, in order to suggest that there nnay well be a point to promising the impossible.

Because I want to follow Professor Waldron in pursuing the idea of justification, I will only note (in order to put aside) the suggestion that the idea of agent-relative justification, which coines in after Hobbes has posited the Right of Nature, may not fully capture the normative role that claims of right play in his or modern discussions. ${ }^{1}$ Instead, I will raise the issue of rights claims as a consequence rather than as a basis of the fundamental idea of justification.

The case of the innocent hostage does indeed make us consider the relevance of a Hobbesian justification for self-defense, but, as

Copyright $\odot 2000$ California Law Review, Inc. California Law Review, Incorporated (CLR) is a California nonprofit corporation. CLR and the authors are solely responsible for the content of their publications.

$\dagger$ Acting Professor of Law, Jurisprudence and Social Policy Program, School of Law, University of California, Berkeley (Boalt Hall). I would like to thank for helpful discussion: Robert Cooter, Claire Finkelstein, Andrew Guzmán, Sanford Kadish, and Jeremy Waldron.

1. I am grateful to Claire Finkelstein for this point. For an exemplary development of a rightsbased account of self-defense, see Claire Finkelstein, A Puzzle about Hobbes on Self-Defense (unpublished manuscript, on file with author). 
Professor Waldron intends, it also makes us consider the fundamental idea of justification itself. I think he is right: It does seem simultaneously sensible and embarrassing that the hostage and the police officer may each shoot the other, even though each is an innocent threat to the other. ${ }^{2}$ But the embarrassment is not merely an apparent logical embarrassment, easily dispelled when we relativize each agent's justification to his aims. What is embarrassing, I think, is the sense that the police officer has not only a different kind of justification than the hostage, but also a better one. The police officer is justified not only in saving his own skin-the agentrelative justification he shares with the hostage-but also in killing the hostage in order to kill the terrorist-a justification grounded in the importance of the other lives he will save aside from his own.

Hobbes's argument for self-defense, as Professor Waldron develops it, rests mainly on the claim that no one could rationally alienate his antecedent right of self-defense - that is, no one could rationally forswear defending himself-because the motivating power of the desire to preserve one's life is such that no one could be expected to commit himself to conduct that would thwart that desire. ${ }^{3}$ It is true that some agents may have other aims that play that role, such as preserving the lives of those they love. But whatever the aim, the nature of the argument is clear. Given the value of the aim, no rational agent would take on an obligation that would defeat that aim, and to refrain from conduct in defense of the aim.

The kind of reason such an aim provides is, as Professor Waldron says, agent-relative: It is a reason for that agent alone. The special value of my life gives me a reason to try to preserve it, a reason that explains why, if I find myself in deadly competition with others, I have reason to favor my own survival. If you and I are both swimming for the proverbial raft that holds only one, I have a positive reason to favor my own survival over yours, simply because it is my life, and so I have reason to try to reach the raft first even though it will mean your death. Indeed, if Hobbes is right, my reason to favor my own life is so strong that it would be unreasonable for me not to favor it no matter how many deaths would result from my act of self-preservation.

Focus on the case where it is just you or I. Any sane moral theory must hold it permissible for me to favor myself in this circumstance. And so we might naturally draw the conclusion that $I$ am justified in swimming for the raft, justified in the sense that what $I$ do is supported by reasons, and violates no obligations towards you. This is a justification I can offer you, in the sense that if I explained my reasoning to you, you could not

2. See Jeremy Waldron, Self-Defense: Agent-Neutral and Agent-Relative Accounts, 88 Calif. L. REv. 711, 715-716 (2000).

3. The argument is actually put in terms of what meaning we can attribute to an agent's words, given that we assume him rational. See id. at 718-721. 
reject it as unsound. But this is a very thin sense of "justification." It gives you no reason to endorse my action, to say "yes, you should have acted as you did," but only removes objections to my action. I want to call this a personal justification. It is a recitation of the valid reasons that the agent has but provides no reasons for anyone else to endorse the action.

Consider now a stranger on the scene, who again can save one but only one of us. He has a positive reason to save either of us, an agentneutral reason grounded im the value of human life, but no agent-relative reason to save either one in particular. Now suppose that our potential savior tells us that he can save even more lives if he departs this scene altogether, and concentrates his efforts elsewhere. He, too, will be justified in what he does, $\mathrm{m}$ the sense that he can offer a coherent explanation of his reasoming. But his explanation, really just an accounting of the value he promotes, is not a justification for us. It provides no reason for us to endorse his choice, given the value we each place upon our own lives. It is, as Professor Waldron suggests, a God's-eye justification, not a justification to anyone on earth. ${ }^{4}$ This being a secular age, let us call this an impersonal justification.

I think what we are looking for is a different form of justification, one that speaks to us but not just in a relative voice, what I will call a political justification. A political justification is not merely a personal statement of reasons, nor is it an impersonal accounting of the values served, but rather a kind of fusion: It is a justification offered to each agent in that it respects the relative value each places on his own aims, but also demands of each agent that he respect the relative value others place on their aims as well. I want to suggest that only a political justification is a full justification, providing reasons that others can endorse, and not merely recognize as valid.

The idea of a political justification is intimately connected with the idea of legitimacy. And the possibility of a gap between personal and political justifications is correlated with the gap Professor Waldron notes, and is noted for, between obligation and legitimacy. ${ }^{5}$ An example may make this clearer. We are familiar with cases where general rules, in the form of law, may legitinately be applied to an agent even if the consequences of the rules do not comport with what the agent has most reason to bring about. Many of us think that if someone we love falls ill, we have special reason to provide that person with the best medical care available. And many of us also think that we have an agent-neutral reason to ensure that everyone-or at least everyone in our political community-has iminimally decent health care, even in the absence of a legal obligation. Alas, these two aims can be in conflict, for if I am paying to support a system of decent health care, then-given iny limited resources-I may not be

4. See id. at 747.

5. See Jeremy Waldron, Theoretical Foundations of Liberalism, in LiBERAL RIGHTS 35 (1993). 
able to provide those I care about with the best medical care available. Confronted with the health problems of someone I love, it may be reasonable, and so justifiable in the personal sense, for me to use my resources for that person, rather than contribute them voluntarily to a general health care charity. ${ }^{6}$ But the agent-relative personal perspective does not translate directly into a limit on what it is legitimate to compel me to do. For I take it that it would be legitimate to compel some contribution by law to the general health system, even if the compelled contribution means that I can provide less for the person I love than I would provide in the absence of the law. ${ }^{7}$ It is reasonable and just to compel me to do what I would not regard myself as having most reason to do.

So how can a law be legitimately applied to me if it makes impossible what I have inost reason to do, and when my reasons, agent-relative and agent-neutral both, are morally impeccable? The answer is that the perspective from which my compulsion is justified acknowledges the importance to me of my health and that of those I love, but it also acknowledges the importance to each agent of his or her own health and that of those he or she loves. Call this perspective the political perspective. The political perspective tries to locate the personal perspective within a generalized framework that is also responsive to agent-neutral reasons. The key point is recognizing that $I$ can share the political perspective and accept it as a basis for common action, without simply eliminating my own, personal, ranking of reasons. I can share it because I can see how it reflects the importance I place on my loved ones' health, even though it does not give full effect to that importance. To the extent I can share it, the demands made from that perspective can be legitimately applied to me. ${ }^{8}$

The difference between the personal perspective and the political perspective can be said, roughly, to mark the progress in contractarian political thought from Hobbes's state of nature to Kant's kingdom of ends, perhaps by way of Locke, and certainly Rousseau. ${ }^{9}$ It is from this perspective that we can justify claims of rights against interpersonal tradeoffs based on aggregative reasoning, but also can justify claims of nonvoluntary

6. Such reasons are, it is now recognized, seen as constitutive of the loving relationship itself. See Samuel Scheffler, Relationships and Responsibilities, 26 PhIL. \& PuB. AfF. 189 (1997). I put aside reasons not to contribute stenıming from collective action concerns, although a central justification of state authority is the resolution of such problems.

7. Libertarians might think it illegitimate, but they would presumably also think it illcgitimate to compel my contribution even if the compellcd contribution did not diminish the resources available for the person I love.

8. Indeed, the very idea of an agent-relative permission may presuppose a political perspective of justification, against whose demands it functions as a permission and not merely a restatement of one's reasons for acting. The political perspective thus supports but also cabins the pcrsonal perspective. See SAMUEl Scheffler, The ReJection of CONSEQUENTIALISM (1982).

9. It is clearly the dominant idea behind much recent post-Kantian political philosophy. See, e.g., Thomas Nagel, Equality and Partiality (1991); John Rawls, Political Liberalism (1993); T.M. Scanlon, What We OWe to Each Other (1999). 
obligation. Thus, the political perspective is not equivalent to a utilitarian perspective. On the other hand, people do not generally have rights to laws that comport with what they themselves have most reason to do; they have only rights to laws that respect what they have most reason to do, even when the laws do not accommodate that reason. Respecting someone's reasonable aim does not entail doing nothing that will frustrate that aim. It entails that their aim may only be frustrated on the basis of an adequate justification. ${ }^{10}$

Return to the hostage case. Both hostage and police officer are justified, in the personal sense, in defending themselves; but only the police officer is justified in the further political sense. His action is justified by reference to a principle that all members of the political community can endorse, since his action will promote what has value to each." ${ }^{11}$ That political justification entails a legal right for the policeman to kill, a valid defense to the charge of murder. Does the fact that the hostage too, from his poimt of view, has most reason to kill, also translate into a political justification? I am unsure. For it seems to me that it could be legitimate to bar the use of lethal force against law enforcement officers who are themselves justified in using lethal force. Such a rule could perhaps be justified in agent-neutral terms by reference to social utility-not just in directly maximizing the number of lives saved, but also im making it easier to persuade police officers to take decisive action in potentially lethal situations.

But as I said before, the justification for restricting self-defense cannot simply consist in agent-neutral reasoning; it must also address the agent-relative value that each agent places on his life, and this is a value that cannot smiply be reallocated between agents. One way to show that it respects the agent-relative perspective is to use a little ex ante imagination, to show how a rule restraining self-defensive action can be in the interest of each, through the additional security it might procure. Incidentally, this may provide a response to Professor Kadish's objection that no one could agree to forgo self-defense, for that would be to purchase less state protection than one had before. Ex ante, someone might well prefer more intrepid and effective police officers at the cost of a marginally restricted right of self-defense. Though the idea of serious punishment for nonaggressive self-defense is immediately appalling, there might well be a point to backing the restriction on self-defensive force with a mild or mainly expressive sanction.

10. This claim about the limits of agent-relative justification is, I think, implicit in Professor Kadish's acknowledgement of the role of social utility in justifying the killing of bystanders. See Sanford H. Kadish, Respect for Life and Regard for Rights in the Criminal Law, in BLAME AND PUNISHMENT 109, 122-23 (1987).

11. Or at least I will assume it can-I am myself unsure about the legitimacy of intentional hostage killing. 
I will return to this point below. The claim I want to make now is just that the perspective of someone in fear of his life is not a suitable perspective for the draftsman of the social contract. Rather, the appropriate perspective is one in which the salience of agent-relative reasoning is appreciated but muted, in which the interests of all can be fairly considered. On Professor Waldron's presentation, neither Hobbes nor Locke delivers.

The second issue I would like to take up concerns an interesting claim Professor Waldron extracts from Hobbes: that no one could be reasonably taken to promise to forgo self-defense, since it would be impossible for anyone in extremis to keep such a promise; and, given common knowledge, therefore, no one would offer anything in return for the promise. (We should note at the outset that the logic of this position generalizes to every sphere of morally relevant action since, for example, there are circumstances in which we could not avoid telling a lie. Thus, by Hobbes's reasoning, no one can be taken to have given up the right to lie. ${ }^{12}$ )

There are two points I would like to make here. The first is logical. Hobbes's argument appears to rest on contrapositive invocation of the maxim that "ought" implies "can": "To be "tyed to impossibilities . . . is contrary to the very nature of compacts." "13 But we need to be wary of casual invocation of the maxim, for "cannots" often cohabit quite happily with "oughts." After I have missed my train, and so will miss my appointment, I cannot make it-but I still ought to be there, and I have done wrong by the person I promised to meet. An agent who promises not to engage in acts of self-defense may literally be unable to control himself and will engage in those acts. But it is certainly possible to maintain that he has thereby broken a promise and ought not be doing what he is. We may excuse him from blame, in light of the determining springs of his action. But excuse is not justification, and there remains a perfectly legitimate sense of "ought" according to which even lunatics ought not do the terrible things they do.

Let me put this point now in service of another. We must take care to distinguish, as Hobbes apparently does not, between a voluntary renunciation of a right to engage in acts of self-defense, and a voluntary renunciation of the acts themselves. Renunciation of a right to perform certain acts may be possible, and so have a point, even if renunciation of the acts themselves is not, and does not have a point. The Hobbesian right consists in a liberty to act in self-defense, which is to say in the absence of a duty not to act in self-defense. To renounce the right is to accept a duty, a duty not to defend oneself. ${ }^{14}$ What follows froin someone's acceptance of a duty not to

12. I owe this point to Robert Cooter.

13. Waldron, supra note 2 , at 722 .

14. The duty (and possibly the prior liberty) are relational: By laying down my liberty with respect to you, I take on a duty to you (but to no one else) not to defend myself. 
do something? Surely not that he will not, in fact, do that thing, for we violate our duties all the time. What follows from accepting a duty is only that it will be wrong not to fulfill the duty. The consequence of promising not to defend oneself is a moral incapacity, not a physical one. One can no longer justifiably defend oneself.

I am trying to clear some space for the idea that one might make a promise one cannot keep, even knowing that one cannot keep it, and even when this is common knowledge. This is because making the promise changes the moral and legal properties that attach to one's actions, and that change may be valuable independently of whether one's underlying actions change too. For one thing, my doing wrong may entitle you to a remedy, albeit one that may flow to your heirs if my self-defense is successful..$^{15}$ If so, then you may offer me a sweet inducement to promise not to defend myself against you, and I will have reason to accept. This is true even if it is common knowledge that if you actually do become a threat to me, I will be unable not to defend myself.

There is another important basis for proimsing the impossible: A penumbra of deterrence may surround the incapacity. Whether or not we literally cannot control our tendency to self-defense in extremis, it is no doubt true that we will sometimes be tempted by merely apparent threats towards self-defensive action in circumstances far short of actual extremity. Moreover, it is also doubtless true that some clever killers may anticipate being able to convince a court that their killing was actually in selfdefense. If we thought we lived in a society of itchy trigger fingers and poor risk judgment, or one of clever killers and a fallible judicial system, then we might take stock of our situation and conclude that we would be better off, ex ante, with a mutual disarmament pact, each forswearing our self-defense liberty. And so we might make such a promise, buttressing it with a deterring sanction, in order to minimize the number of cases within agents' control, even though there will be some cases beyond our control. The case is even stronger, as I remarked above, for promising not to defend myself only against justified force. In either case, there could be substantial reason to accept "such a hollow undertaking." 16

Let me be clear that I have not tried to argue against a complete right of self-defense, a right including the right to defend against justified force. I have, rather, tried to show what is involved in justifying that defense, and how we must go beyond the agents' personal point of view, even if we must not follow Locke and arrogate to ourselves the point of view of the universe. Second; I have tried to show how, from that more limited point of view, it might well make sense to forgo that right, notwithstanding our

15. I owe this point to Andrew Guzmán.

16. Waldron, supra note 2 , at 723. 
[Vol. 88:751

physical limitations. These are, then, two different forms of transcendence, attainable even by self-interested agents. 